be nonexistent or of negligible importance in this early period of history, are in for a surprise and a treat.

The planned six-volume work on the history of Wisconsin is off and running with the appearance of this book. The remaining volumes have been announced for publication in 1975-1976, and they are eagerly awaited. If the other five are within hailing distance of the quality and style of Miss Smith's magnum opus, the state of Wisconsin and readers of history everywhere will be fortunate indeed. Those who are charged with the keeping of Iowa history should take heed and follow the Wisconsin example as closely as possible; in the meanwhile, every school, college, and public library in Iowa should invest in this nearly perfect book.

Leland L. Sage Cedar Falls

\title{
\# \#
}

The Price of Vision: The Diary of Henry A. Wallace, 1942-1946, edited with an introduction by John Morton Blum. Boston: Houghton Mifflin Co. 1973. pp. x, 707, index. $\$ 15.00$

In recent years, perhaps because of the Vietnam conflict and the waning of the Cold War, historians have become increasingly intrigued by the question of what happened to American liberalism during and immediately after World War II. The publication of this diary, therefore, is a welcome addition to the rapidly expanding literature on the topic. Moreover, Yale historian John Morton Blum's editing, particularly his copious footnotes, greatly enhances the usefulness of the diary as an historical document. Even though he has included only about twenty-five percent of the diary Henry A. Wallace rigorously kept between 1942 and 1946now deposited in the Special Collections Department of the University of Iowa Libraries and soon to be opened to other researchers-it is unlikely that many historians will find it necessary to go beyond what is contained in The Price Of Vision. 
In an admirably written introduction entitled "Portrait of the Diarist," Blum notes how ironic it is that the Iowan is "still remembered more for his occasional fallibility than for his extraordinary foresight." (p. 49) It is easy to sympathize with Blum on this point, for the Wallace who emerges from these pages is a far cry from the often cruel caricatures of him as a purblind ideologue which were so prevalent during the most chilling years of the Cold War. Indeed, one of the things that repeatedly struck me was the modernity of Wallace's concerns about population pressures, food production, natural resources and their allocation, Arabs and their oil, international cartels, racism, poverty, defense spending, the relationship between big corporations and the military, inflation, and unemployment-issues disturbingly familiar to Americans in the 1970s.

Above all, Wallace hoped the defeat of Germany and Japan would usher in what he liked to call "the century of the common man," a time when the lessening of international tension would produce genuine world peace. Thus it was with a growing sense of alarm, clearly evident in this book, that he watched the developing rivalry between the United States and Russia as the war ended. Much of the blame for the increasing disharmony between the two great powers, Wallace believed, rested with Truman and some of his advisors who failed to recognize Russia's need for both security from future attack and the capital necessary to rebuild a shattered economy. When Wallace began to speak out on foreign policy questions in 1946, Truman fired him from his post as Secretary of Commerce. Wallace's criticisms of American policy during the early stages of the Cold War anticipate by twenty years the arguments of revisionist historians who charge American culpability played a crucial role in initiating the frightful struggle.

The Iowan, naturally, was not always visionary, and his response in some situations suggests a surprising degree of political ineptitude for one who had been in Washington a long time. In 1944, for example, Wallace obviously wanted again to be Roosevelt's running mate, yet his diary indicates that he made almost no fight to remain on the ticket. Even after learning how the President had manuvered to replace him with Truman, Wallace found it difficult to criticize F.D.R. About the only entry that ap- 
proaches censure of Roosevelt came when Wallace, after listening to discussions of the Palestine question, observed: "The President certainly is a waterman. He looks one direction and rows the other with utmost skill." (p. 313) On the other hand, from the beginning, Wallace had doubts about Truman's ability to handle the awesome responsibilities of the Presidency. Because he was so often involved in decision-making at the highest levels, Wallace's diary illuminates one of the most critical periods in American history. While it will be of greatest use for recent American historians, the non-professional will find rewarding reading in this diary of one of Iowa's most famous sons.

Peter L. Petersen

West Texas State University

\section{\# \#}

Demise of the Democracy: The Copperhead Press in Iowa, by David L. Lendt. Ames: The Iowa State University Press, Replica Edition. 1973.

David L. Lendt's study of the Copperhead press in Iowa during the Civil War era is one of mixed quality. Over-all, he cogently argues that the state's Republican majority persecuted the Copperhead press for political purposes. He demonstrates that these anti-Lincoln, anti-war newspapers were not only a manifestation of pro-Southern sentiment; rather, they served also as forums for immigrants and social, economic and political conservatives. Lendt further suggests that Iowa's Copperhead editors came mainly from the ranks of the state's Democratic newspapermen who saw themselves as the "loyal opposition." These editors advocated neither violence nor lawlessness and at no time politically threatened Iowa's pro-Union stance. 
Copyright of Annals of Iowa is the property of State of Iowa, by \& through the State Historical Society of Iowa and its content may not be copied or emailed to multiple sites or posted to a listserv without the copyright holder's express written permission. However, users may print, download, or email articles for individual use. 